\title{
Expression and regulation of glucose transporter 8 in rat Leydig cells
}

\author{
Y Chen ${ }^{1,3,4}, M$ L Nagpal ${ }^{1,3}$ and $\operatorname{T~Lin~}^{1,2,3}$ \\ ${ }^{1}$ Research Services, WJB Dorn Veterans Medical Center, Columbia, South Carolina 29201, USA \\ ${ }^{2}$ Primary Care Services and Speciality Medicine, WJB Dorn Veterans Medical Center, Columbia, South Carolina 29201, USA \\ ${ }^{3}$ Department of Medicine, University of South Carolina School of Medicine, Columbia, South Carolina 29208, USA \\ ${ }^{4}$ Department of Biology, School of Life Science, Xiamen University, Xiamen, Fujian 361005, People's Republic of China \\ (Requests for offprints should be addressed to T Lin, Department of Medicine, University of South Carolina School of Medicine, Medical Library Building, \\ Suite 316, Columbia, South Carolina 29208, USA; Email: lin@med.sc.edu)
}

\begin{abstract}
Basal and LH/human chorionic gonadotropin (hCG)stimulated testosterone formation by Leydig cells is dependent on ambient glucose levels. Inhibition of glucose uptake is associated with decreased testosterone formation. Recently, glucose transporter 8 (GLUT8) has been shown to be highly expressed in the testis. In the present study, we have investigated the expression and regulation of the GLUT8 gene in rat Leydig cells. Primers were designed by using sequences that are not conserved in GLUT1 to GLUT5 and that contain the glycosylation region of GLUT8. This yielded an amplicon of $186 \mathrm{bp}$. The tissue-specific expression experiments in adult rat (55- to 65-day-old) tissues revealed that GLUT8 is expressed predominantly in the testis, in smaller amounts in heart and kidney, and in negligible amounts in liver and spleen. Furthermore, GLUT8 mRNA was found to be highly expressed in crude interstitial cells, Leydig cells and testicular and epididymal germ cells. In prepubertal rat (20-day-old) tissues, GLUT8 expression was compara-
\end{abstract}

tively much lower than in the adult rat tissues. By comparative RT-PCR, hCG caused dose- and timedependent increases of GLUT8 mRNA levels. hCG and IGF-I had synergistic effects on GLUT8 mRNA and protein expression. GLUT1 and GLUT3 were also found to be expressed in Leydig cells. However, neither GLUT1 nor GLUT3 were affected by treatments with hCG, IGF-I or hCG and IGF-I combined. The addition of murine interleukin- $1 \alpha(\mathrm{mIL}-1 \alpha ; 10 \mathrm{ng} / \mathrm{ml})$, murine tumor necrosis factor $-\alpha(\mathrm{mTNF}-\alpha ; 10 \mathrm{ng} / \mathrm{ml})$, murine interferon- $\gamma$ $(\mathrm{mIFN}-\gamma ; 500 \mathrm{U} / \mathrm{ml}$ ) separately or in combination decreased hCG-induced GLUT8 mRNA levels significantly. In conclusion, GLUT8 mRNA in Leydig cells was positively regulated by hCG and IGF-I and downregulated by cytokines, mIL- $1 \alpha$, mTNF- $\alpha$ and mIFN- $\gamma$. These results indicate that hCG, growth factors and cytokines affect Leydig cell steroidogenesis by modulating GLUT8 expression.

Journal of Endocrinology (2003) 179, 63-72

\section{Introduction}

Hexose transport into mammalian cells is catalyzed by a small family of 45 to $55 \mathrm{kDa}$ membrane proteins that belong to the larger family of transport facilitators (for review see Joost \& Thorens 2001). Glucose transporters play a key role in the transport of glucose throughout the body: glucose storage in the liver, insulin-dependent glucose uptake in muscles and adipocytes, and glucose sensing by pancreatic $\beta$ cells. They are differentially expressed in various tissues and organs in the body, and one of these newly cloned glucose transporters, GLUT8, has been found to be highly expressed in the testis (Doege et al. 2000a, Ibberson et al. 2000).

On the basis of sequence similarities and characteristic elements, the GLUT family can be divided into three subclasses, namely class I (the previously known glucose transporters GLUT1-4), class II (the previously known fructose transporters GLUT5, GLUT7, GLUT9 and GLUT11), and class III (GLUT6, 8, 10, 12 and the $\mathrm{H}^{+}$/myo-inositol transporter (HMIT1)) (Joost \& Thorens 2001). GLUT1 is expressed in most cells, particularly in erythrocytes and it appears to provide a basal supply of glucose (Mueckler et al. 1985). GLUT2 is predominantly expressed in the liver and pancreas (Fukumoto et al. 1988), GLUT3 in neuronal cells (Kayano et al. 1988), GLUT4 in muscle, heart and adipose tissue (Fukumoto et al. 1989), and GLUT5 in the intestines, kidney and testis (Kayano et al. 1990). GLUT6 is expressed predominantly in the brain, spleen and peripheral leucocytes (Doege et al. 2000b, Joost et al. 2001). GLUT8 has been shown to be specifically expressed in adult testis; it has been characterized and cloned independently by two groups: Doege $e t$ al. (2000a) and Ibberson et al. (2000). GLUT9 is expressed 
predominantly in the liver and kidney (Phay et al. 2000). GLUT10 has been identified in the liver and pancreas (Doege et al. 2001a, McVie-Wylie et al. 2001). GLUT11 is found in the heart and skeletal muscle (Doege et al. 2001b). Sugar transport has been reported for GLUT6, 8 and 11; HMIT1 has been shown to be an $\mathrm{H}^{+}$/myo-inositol cotransporter (Joost \& Thorens 2001).

It has long been established that glucose is essential for Leydig cell steroidogenesis. Both basal and luteinizing hormone (LH)/human chorionic gonadotropin (hCG)stimulated testosterone synthesis depend on ambient glucose concentrations (Murono et al. 1982). In addition, inhibition of glucose uptake is associated with decreased testosterone formation. However, there is limited information regarding the regulation of glucose uptake by Leydig cells.

LH/hCG is the major regulatory factor of Leydig cell steroidogenesis. Many growth factors and cytokines also modulate Leydig cell steroidogenesis (Saez 1994). Insulinlike growth factor-I (IGF-I) enhances LH/hCGstimulated testosterone formation (Lin 1996), and high levels of IGF-I are expressed in Leydig cells (Lin et al. 1986). In primary cultures of Leydig cells, interleukin-1 (IL-1) is a potent inhibitor of testosterone formation (Calkins et al. 1988, 1990a). IL-1 blocks hCG-stimulated cAMP formation and cytochrome P450 side-chain cleavage (P450 scc) mRNA expression (Lin et al. 1991a). The inhibitory effects of IL-1 can be reversed by the concomitant addition of IL-1 receptor antagonist (Lin et al. 1991b). IL-1 also down-regulates IGF-I gene expression in Leydig cells (Lin et al. 1992). Other cytokines, tumor necrosis factor- $\alpha$ (TNF- $\alpha$ ) and interferon- $\gamma$ (IFN- $\gamma$ ), are also potent inhibitors of Leydig cell testosterone formation (Calkins et al. 1990b, Lin et al. 1994, 1998a). In addition to the inhibition of P450 scc mRNAs, IFN- $\gamma$ also inhibits hCG-stimulated steroidogenic acute regulatory protein (StAR) gene expression (Lin et al. 1998a). In the present study, we have investigated the effects of hCG, IGF-I and cytokines on GLUT8 expression in Leydig cells.

\section{Materials and Methods}

\section{Isolation and culture of rat interstitial cells, and partially} purified and highly purified Leydig cells

Normal male Sprague-Dawley rats (20 and 55-65 days old; Charles River, Raleigh, NC, USA) were killed after asphyxiation in a $\mathrm{CO}_{2}$ chamber and testes were removed. The Leydig cells were isolated as described previously by Klinefelter et al. (1987) with minor modifications (Lin et al. 1990). The protocol was approved by the Institutional Animal Care and Use Committee. In brief, the testes were perfused with Dulbecco's modified Eagle's medium/Ham's F-12 (DMEM/F12), followed by collagenase digestion $(0.25 \mathrm{mg} / \mathrm{ml})$ of the decapsulated testes at $34{ }^{\circ} \mathrm{C}$ in a shaking water bath at 100 cycles/min for
$20 \mathrm{~min}$. The digestion mixture was filtered through four layers of cheese cloth to separate interstitial cells and seminiferous tubules. Seminiferous tubules were saved for isolation of germ cells. The filtrate containing interstitial cells was centrifuged at $250 \boldsymbol{g}$ for $10 \mathrm{~min}$ at $4{ }^{\circ} \mathrm{C}$, the pellet was washed twice with DMEM/F12 and the interstitial cells were re-suspended in DMEM/F12. The interstitial cells were further fractionated by size using a Beckman elutriator rotor, model 5.0 with a $5 \mathrm{ml}$ chamber at a speed of 2000 r.p.m. and a flow rate of $16 \mathrm{ml} / \mathrm{min}$. The fraction obtained was termed as 'partially purified Leydig cells'. This fraction was centrifuged through a 60\% Percoll gradient at $27000 \mathrm{~g}$ at $4{ }^{\circ} \mathrm{C}$ for $60 \mathrm{~min}$. The heavier fraction was isolated and termed as 'highly purified Leydig cells'. Using $3 \beta$-hydroxysteroid dehydrogenase staining (Lin et al. 1990), more than $95 \%$ cells stained positive. The highly purified Leydig cells may still have a very minor contamination with macrophages and sperm cells. Since only Leydig cells express LH/hCG receptors, the induction of GLUT8 by hCG is specific for Leydig cells.

Purified Leydig cells were cultured in DMEM/F12 with $0 \cdot 1 \%$ fetal calf serum (FBS), $15 \mathrm{mM}$ HEPES, 100 $\mathrm{U} / \mathrm{ml}$ penicillin, $100 \mu \mathrm{g} / \mathrm{ml}$ streptomycin, IGF-I or various cytokines for $24 \mathrm{~h}$. After medium change, cells were treated without or with IGF-I, cytokines and hCG $(1-50 \mathrm{ng} / \mathrm{ml})$ for an additional $6 \mathrm{~h}$. Total cellular RNA was then extracted. Murine (m) IL-1 $\alpha$, mTNF- $\alpha$ and mIFN- $\gamma$ were obtained from Genzyme Corp. (Cambridge, MA, USA).

\section{Isolation of testicular germ cells}

For the isolation of testicular germ cells, the procedure of Janulis et al. (1998) was used with the exception of the trypsinization step. Seminiferous tubules were cut into small pieces and sperm were dispersed out with gentle pipetting. The resulting cell suspension was filtered through fine nylon mesh to remove clumps of cells and tissue. The supernatant containing testicular germ cells was transferred to a new centrifuge tube, and spun at 1500 r.p.m. for $5 \mathrm{~min}$. The supernatant was discarded, and the pellet was washed three times with DMEM/F12. Further separation of cell types was accomplished by unit gravity sedimentation through a bovine serum albumin (BSA) gradient (Janulis et al. 1998). The germ cells were pooled, pelleted and used for RNA extraction.

\section{Isolation of epididymal germ cells}

Normal male Sprague-Dawley rats (55-65 days old) were killed by asphyxiation in a $\mathrm{CO}_{2}$ chamber and the epididymis was removed. The epididymal fluid and spermatozoa were obtained by perfusion of the caudal region with $0.02 \mathrm{M}$ phosphate buffer, $\mathrm{pH} 6.5$, containing $0 \cdot 15 \mathrm{M} \mathrm{NaCl}$. The spermatozoa were sedimented by centrifugation at $3000 \mathrm{~g}$ for $10 \mathrm{~min}$ at $4{ }^{\circ} \mathrm{C}$. The 
spermatozoa were washed twice with $5 \mathrm{ml} 0.3 \mathrm{M} \mathrm{KCl}$ in the phosphate buffer and once with $5 \mathrm{ml}$ buffer alone (Sosa et al. 1991).

\section{Isolation of total RNA}

Total cellular RNA was extracted from samples using Trizol reagent (Life Technologies, Inc., Gaithersburg, MD, USA). RNA was treated with ribonuclease-free DNaseI (Life Technologies, Inc.) to remove any contaminating DNA. The purity and yield of isolated RNA were determined by absorbance at 260 and $280 \mathrm{~nm}$. The integrity of the RNA was confirmed by performing denaturing gel electrophoresis.

\section{Comparative RT-PCR}

DNA was generated using $5 \mu \mathrm{g}$ total RNA, $2.5 \mu \mathrm{g}$ oligo-dT primer and mouse Moloney leukemia virus reverse transcriptase (Fisher Scientific, Suwanee, GA, USA) at $42{ }^{\circ} \mathrm{C}$ for $1 \mathrm{~h}$. Total cDNA ( $1 / 20$ of the reaction) was used as the template for PCR. RT-PCR of the L19 ribosomal protein gene was used as a control for RNA input. L19 primers were from two different exons spanning an intron junction that served as a control for the absence of contaminating genomic DNA. The L19 gene was amplified by the primer pairs: 5'-GAAATCGCCAATGCCAACTC-3' forward and 5'-TCTTAGACCTGCGAGCCTCA-3' reverse, which yielded an amplicon of $405 \mathrm{bp}$ (Manna et al. 2002).

GLUT8 primers were selected from the published aligned sequences of human and mouse GLUT8 (Doege et al. 2000a) and further compared with GenBank sequences of rat GLUT8 (GenBank accession no. 7592743 (Rattus norvegicus GLUT8)). The sequences used for designing primers for GLUT8 are not conserved in GLUT1-GLUT5, and contained the glycosylation region of GLUT8. The GLUT8 primers were: 5'-TCATGGACAGAGCAGGGCG-3' forward and 5'-GCCAGCCAGGCCAGCCCCA-3' reverse, which yielded an amplicon of $186 \mathrm{bp}$. These primers also matched the sequences of GLUTX1 (Ibberson et al. 2000), and the PCR product obtained had the sequences of helix 8 and loop 9 of GLUT8.

GLUT1 and GLUT3 primers were used as described by Ishimura et al. (2002). These were further compared with GenBank sequences of the rat (accession no. 20301951 (GLUT1) and no. 8394300 (GLUT3)). The GLUT1 primers yielded a $298 \mathrm{bp}$ product, whereas GLUT3 primers yielded a $426 \mathrm{bp}$ product (as also described by Ishimura et al. 2002).

PCR conditions were optimized with buffers for the PCR system (Fisher Scientific). The reaction buffer contained $20 \mathrm{mM}$ Tris- $\mathrm{HCl}$ (pH 8.8), $10 \mathrm{mM} \mathrm{KCl}, 10 \mathrm{mM}$ $\left(\mathrm{NH}_{4}\right)_{2} \mathrm{SO}_{4}, 2 \mathrm{mM} \mathrm{MgSO}, 0 \cdot 1 \%$ Triton $\mathrm{X}-100$ and $100 \mu \mathrm{g}$ BSA. The amplification reaction mixture also contained $0.2 \mathrm{mM}$ of each dNTP, $10 \mathrm{pM}$ of each primer, cDNA template and $1.5 \mathrm{U}$ Taq DNA polymerase. The amplifications were carried out on GeneAmp PCR System 9700 (Applied Biosystems, Foster City, CA, USA). Cycling programs were $94^{\circ} \mathrm{C}$ for $2 \mathrm{~min}$, followed by $26-40$ cycles of $94^{\circ} \mathrm{C}$ for $30 \mathrm{~s}, 48^{\circ} \mathrm{C}$ for $30 \mathrm{~s}, 72^{\circ} \mathrm{C}$ for $1.5 \mathrm{~min}$, with a final extension of $72{ }^{\circ} \mathrm{C}$ for $4 \mathrm{~min}$. All experiments were repeated at least three times with comparable results.

\section{Protein extraction and Western blot analysis}

Cultured Leydig cells were washed twice with $1 \times$ phosphate-buffered saline $(\mathrm{PBS})$ at room temperature, lysed in RIPA buffer $(1 \times$ PBS, $1 \%$ Nonidet P-40, $0 \cdot 5 \%$ sodium deoxycholate, $0 \cdot 1 \%$ SDS, $0 \cdot 1 \mathrm{mg} / \mathrm{ml}$ phenylmethylsulfonyl fluoride, $0 \cdot 1 \%$ aprotinin and $1 \mathrm{mM}$ sodium orthovanadate) at $4{ }^{\circ} \mathrm{C}$, and passed through a 21 gauge needle to shear DNA. The cell lysates were centrifuged and the protein content was determined by the bicinchoninic acid protein assay procedure (Pierce, Rockford, IL, USA). The samples were mixed with an equal volume of $2 \times$ SDS electrophoresis buffer $(1.0 \mathrm{ml}$ glycerol, $0.5 \mathrm{ml}$ $\beta$-mercaptoethanol, $3.0 \mathrm{ml} 10 \% \mathrm{SDS}, 1 \cdot 25 \mathrm{ml} 1.0 \mathrm{M}$ Tris$\mathrm{HCl}, \mathrm{pH} 6.7$ and $1 \mathrm{mg}$ bromophenol blue ) and boiled for $3 \mathrm{~min}$. The protein samples were then separated by 4-15\% SDS-PAGE (BIO-RAD Laboratories, Hercules, CA, USA) at $100 \mathrm{~V}$ for $3 \mathrm{~h}$ at $4{ }^{\circ} \mathrm{C}$. The proteins were transferred to polyvinylidene fluoride membrane (Amersham Biosciences, Piscataway, NJ, USA) using an electroblotting apparatus (BIO-RAD Laboratories) at $14 \mathrm{~V}$ overnight at $4{ }^{\circ} \mathrm{C}$. Western blot analyses were performed according to the Western immunoblotting procedures of Santa Cruz Biotechnology, Inc. (Santa Cruz, CA, USA). The primary antibodies used were polyclonal goat anti-rat GLUT8 IgG $(1 \mu \mathrm{g} / \mathrm{ml})$. The secondary antibody used was polyclonal bovine anti-goat IgG-HRP $(0 \cdot 4 \mu \mathrm{g}, \quad 1: 1000$ dilution). The specific signal was detected by chemiluminescence using Chemiluminescence Luminol Reagent from Santa Cruz Biotechnology, Inc. according to the luminal data sheet. All blots were run using actin (goat anti-rat actin IgG from Santa Cruz Biotechnology, Inc.) as the internal control. The membranes were subjected to autoradiography and an optimal exposure time determined within the range of linearity. The results are reported as a ratio between the glucose transporter protein and the $\beta$-actin protein.

\section{Statistical analysis}

Results are the means \pm S.E.M. of four to six separate experiments. One-way ANOVA followed by NewmanKeuls multiple comparison tests were used for statistical analyses (GraphPad Prism, version 3.0; GraphPad Software, Inc., San Diego, CA, USA). P $\leq 0 \cdot 05$ was considered statistically significant. 


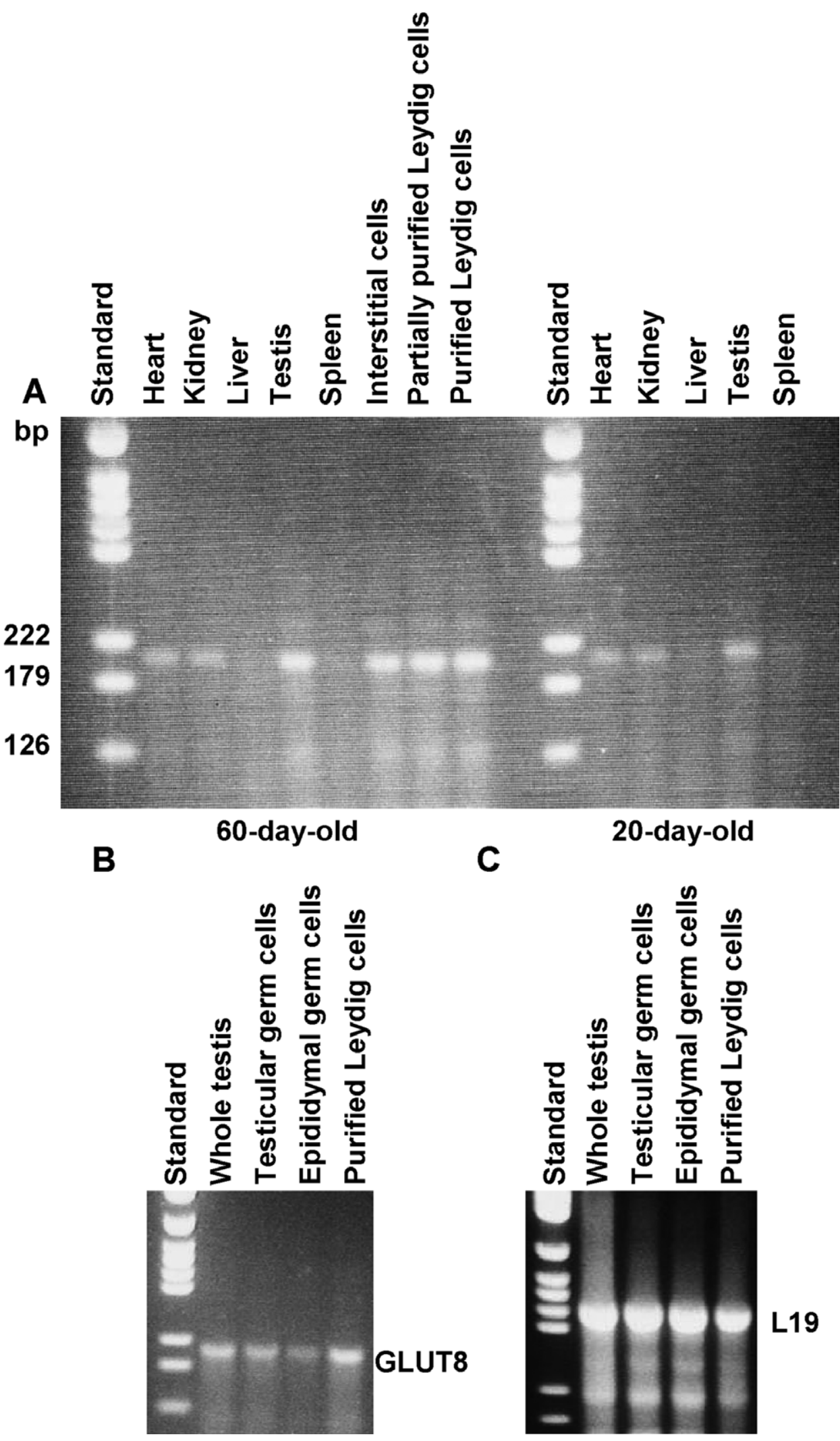


A
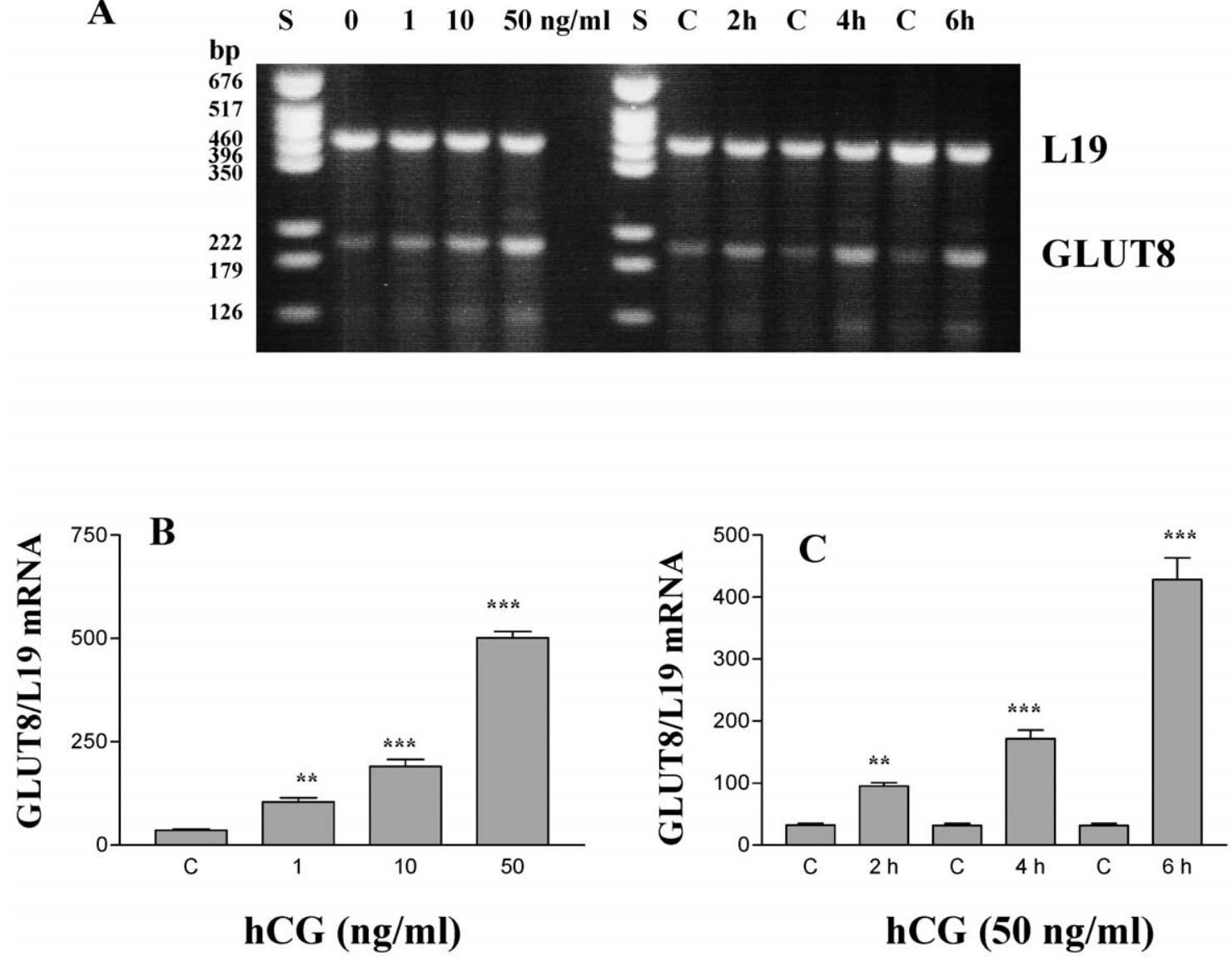

Figure 2 Dose-response and time-course effects of hCG on GLUT8 expression. Purified adult rat Leydig cells were cultured overnight. After medium change, cells were treated with various doses of hCG $(0-50 \mathrm{ng} / \mathrm{ml})$ for $6 \mathrm{~h}$, and for various time-periods with hCG $(10 \mathrm{ng} / \mathrm{ml})$. GLUT8 and L19 primer sets were added to the CDNA template and PCR was carried out for 27 cycles. Lane S indicates standard DNA markers, and the numbers on the left indicate the sizes of the bands in base pairs. (A) A representative agarose gel, (B) GLUT8/L19 mRNA plot for dose-response and (C) GLUT8/L19 mRNA plot for the time-course. (C, control). Data are presented as means \pm S.E.M., $n=6 .{ }^{* *} P<0 \cdot 01$ and ${ }^{* * *} P<0 \cdot 001$ as compared with controls.

\section{Results}

Tissue-specific expression of GLUT8

The GLUT8 RT-PCR product, a band of $186 \mathrm{bp}$, was expressed predominantly in the testis, in smaller amounts in heart and kidney, and in negligible amounts in liver and spleen. The highest abundance was found in the interstitial cells and in partially purified and highly purified Leydig cells. Immature rat testes had relatively low levels of mRNA in all tissues (Fig. 1A). Furthermore, we found that GLUT8 mRNA was also expressed in testicular and epididymal germ cells (Fig. 1B and C).

Dose dependence and time-course of hCG-induced GLUT8 expression

To examine the dose-dependent effects of hCG and their time-course on GLUT8 expression, Leydig cells $\left(8-10 \times 10^{6}\right.$ cells/well $)$ were cultured overnight. After medium change, cells were treated with various

Figure 1 (A) RT-PCR of GLUT8 of various tissues of adult (60-day-old) and prepubertal (20-day-old) rats. Total RNA was extracted. GLUT8 primers were added to the CDNA template and PCR was carried out for 35 cycles. The lane labeled Standard indicates DNA markers, and the numbers on the left indicate the sizes of the bands in base pairs. The GLUT8 amplified product was 186 bp. Expression of (B) GLUT8 (186 bp) and (C) L19 (405 bp) in adult testis, testicular germ cells, epididymal germ cells and purified Leydig cells. 


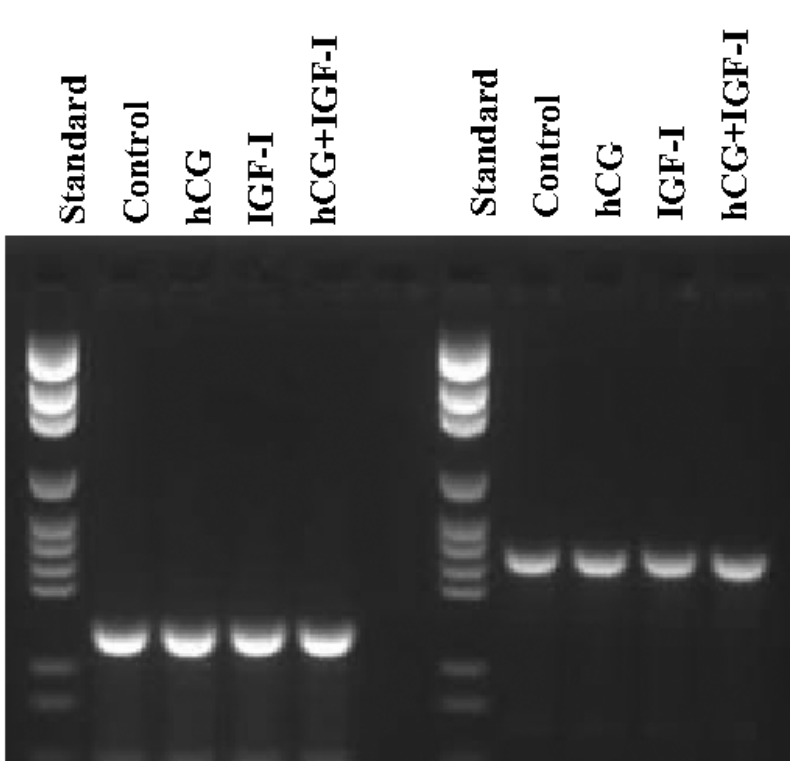

\section{GLUT1}

GLUT3

Figure 3 Effects of hCG, IGF-I, or hCG+IGF-I on GLUT1 or GLUT3 mRNA expression in rat Leydig cells. Leydig cells were cultured without or with IGF-I $(100 \mathrm{ng} / \mathrm{ml})$ for $24 \mathrm{~h}$. After medium change, cells were treated without or with IGF-I $(100 \mathrm{ng} / \mathrm{ml})$ and/or hCG $(10 \mathrm{ng} / \mathrm{ml})$ for an additional $6 \mathrm{~h}$. Total cellular RNA was extracted. GLUT1 and GLUT3 primer sets were added to the cDNA template, and PCR was carried out for 27 cycles.

concentrations of hCG (1, 10 and $50 \mathrm{ng} / \mathrm{ml})$ for $6 \mathrm{~h}$. RT-PCR analysis was carried out for GLUT8 and L19 ribosomal protein in the same tube. The upper band (405 bp) of L19 ribosomal protein did not show any significant change with the treatments. In contrast, hCG caused a dose-dependent increase in GLUT8 mRNA levels (lower band, $186 \mathrm{bp}$; Fig. 2A and B). hCG in a concentration of $50 \mathrm{ng} / \mathrm{ml}$ increased GLUT8 mRNA by more than 7-fold. hCG also increased GLUT8 mRNA levels in a time-dependent manner: $1 \cdot 5$-fold at $2 \mathrm{~h}, 3$-fold at $4 \mathrm{~h}$ and $5 \cdot 5$-fold at $6 \mathrm{~h}$ (Fig. $2 \mathrm{~A}$ and $\mathrm{C}$ ). A submaximal concentration of hCG $(10 \mathrm{ng} / \mathrm{ml})$ and an incubation time of $6 \mathrm{~h}$ were used for all subsequent experiments.

\section{Effect of IGF-I and hCG on GLUT1 and GLUT3 mRNA expression in adult rat Leydig cells}

Purified Leydig cells were cultured in DMEM/F-12 containing $0 \cdot 1 \%$ FBS without or with IGF-I $(100 \mathrm{ng} / \mathrm{ml})$ for $24 \mathrm{~h}$. After medium change (serum-free DMEM/F12), cells were treated without or with IGF-I $(100 \mathrm{ng} / \mathrm{ml})$ and/or hCG $(10 \mathrm{ng} / \mathrm{ml})$ for $6 \mathrm{~h}$. There were no significant effects on the expression of GLUT1 or GLUT3 when treated with hCG or IGF-I or hCG+IGF-I, as determined by RT-PCR. The expression of GLUT1 was 3- to 4-fold more than that of GLUT3 in both control and treated cells (Fig. 3).
Effect of IGF-I and hCG on GLUT8 expression in adult and prepubertal rat Leydig cells

Purified Leydig cells were cultured in DMEM/F-12 containing $0 \cdot 1 \%$ FBS without or with IGF-I $(100 \mathrm{ng} / \mathrm{ml})$ for $24 \mathrm{~h}$. After medium change (serum-free DMEM/F12), cells were treated without or with IGF-I $(100 \mathrm{ng} / \mathrm{ml})$ and/or hCG $(10 \mathrm{ng} / \mathrm{ml})$ for $6 \mathrm{~h}$. In adult rat Leydig cells, IGF-I increased the expression of GLUT8 by 3-fold. hCG $(10 \mathrm{ng} / \mathrm{ml})$ treatment alone increased GLUT8 mRNA levels by 4-fold. With concomitant addition of both IGF-I and hCG, GLUT8 mRNA levels were further enhanced 7-fold (Fig. 4A and B). Basal testosterone levels were $8.5 \pm 1 \cdot 1 \mathrm{ng} / \mathrm{ml}$. In the presence of IGF-I $(100 \mathrm{ng} / \mathrm{ml})$, testosterone formation increased to $15 \cdot 3 \pm$ $2 \cdot 1 \mathrm{ng} / \mathrm{ml} \quad(P<0 \cdot 05)$. hCG increased testosterone formation to $112 \cdot 0 \pm 4 \cdot 7 \mathrm{ng} / \mathrm{ml}(P<0 \cdot 001)$. With concomitant addition of $\mathrm{hCG}$ and IGF-I, testosterone formation was further increased to $176 \pm 4.7 \mathrm{ng} / \mathrm{ml}$ $(P<0.001 ; n=4)$. The expression of GLUT8 in prepubertal rat Leydig cells was lower than that of adult rat Leydig cells, its expression was significantly induced by treatment with IGF-I, hCG or both (Fig. 4A and B).

Effect of IGF-I and hCG on GLUT8 protein expression in adult rat Leydig cells

Purified Leydig cells were cultured in DMEM/F-12 containing $0 \cdot 1 \%$ FBS without or with IGF-I $(100 \mathrm{ng} / \mathrm{ml})$ for $24 \mathrm{~h}$. After medium change (serum-free DMEM/F12), cells were treated without or with IGF-I $(100 \mathrm{ng} / \mathrm{ml})$ and/or $\mathrm{hCG}(10 \mathrm{ng} / \mathrm{ml})$ for $6 \mathrm{~h}$. GLUT8 protein was observed as a single band at $37 \mathrm{kDa}$. There were significant increases in GLUT8 protein levels associated with hCG, IGF-I or the combination of both (Fig. 5).

Effects of $m I L-1 \alpha, m T N F-\alpha$ and $m I F N-\gamma$ on hCG-induced GLUT8 $m R N A$ expression

Various cytokines have been shown to affect Leydig cell steroidogenesis. We have investigated the effects of cytokines on hCG-induced GLUT8 expression. Purified Leydig cells were cultured overnight with various cytokines. After medium change, cells were cultured with cytokines and without or with hCG $(10 \mathrm{ng} / \mathrm{ml})$ for an additional $6 \mathrm{~h}$. hCG increased GLUT8 mRNA levels by 5 -fold. The levels of hCG-induced GLUT8 mRNA were decreased by treatment with $\mathrm{mIL}-1 \alpha(10 \mathrm{ng} / \mathrm{ml})$, mTNF- $\alpha$ (10 ng/ml) or mIFN- $\gamma$ (500 units/ml) (40\%, $50 \%$ and $40 \%$ respectively). Concomitant addition of mIL- $1 \alpha$, mTNF- $\alpha$ and mIFN- $\gamma$ further reduced GLUT8 mRNA levels to $25 \%$ of the cells treated with hCG only (Fig. 6A and B).

\section{Discussion}

Transmembrane glucose uptake is the rate-limiting step in glucose metabolism. Facilitated transport of glucose is 
A

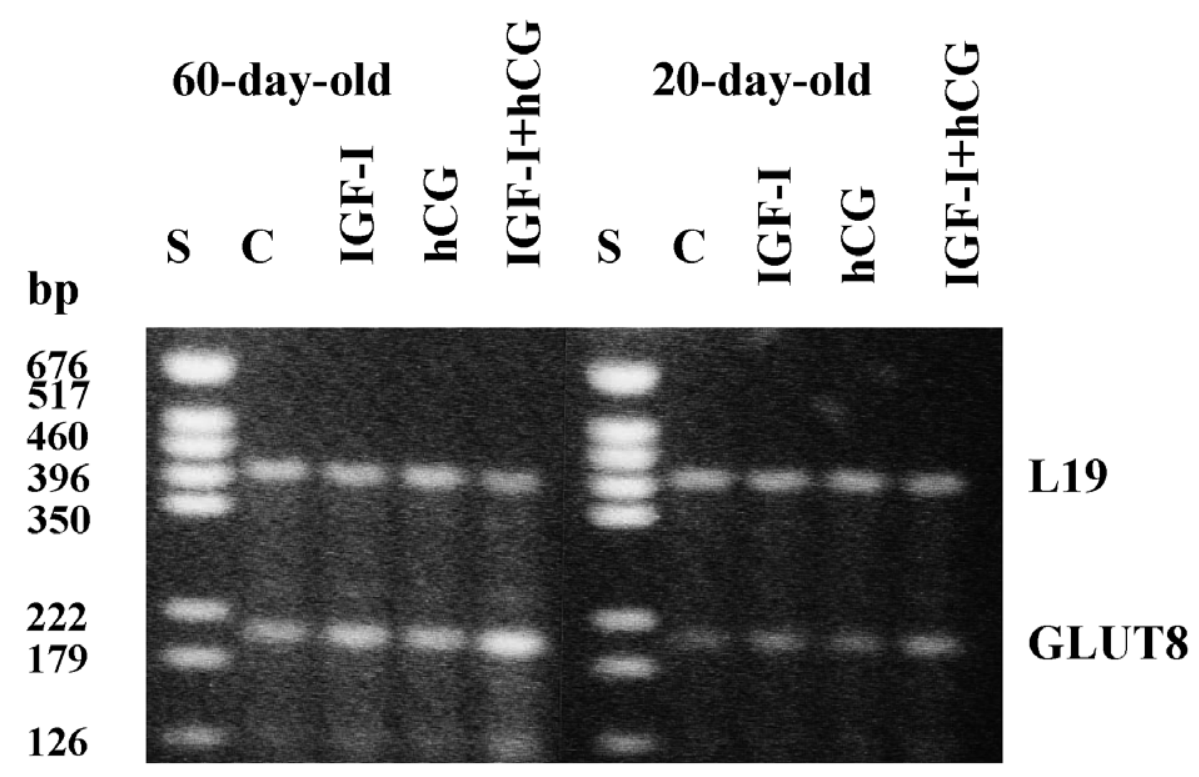

B

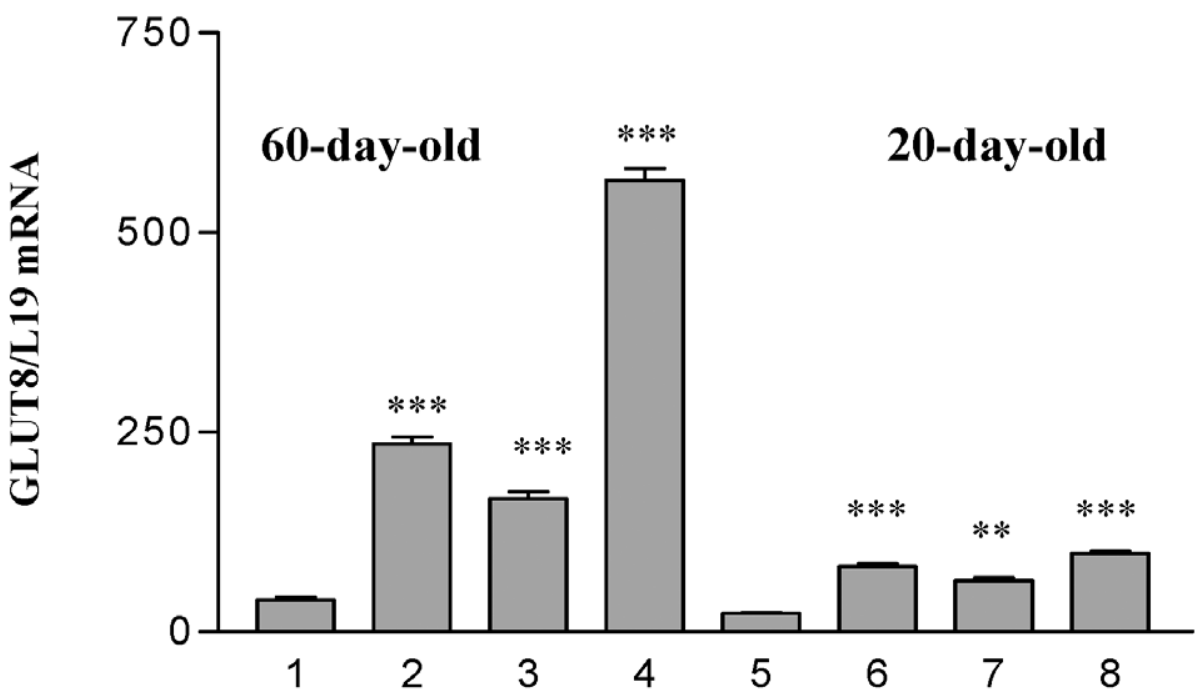

Figure 4 Effects of hCG and IGF-I on GLUT8 expression of adult and prepubertal rat Leydig cells. Leydig cells were cultured without or with IGF-I $(100 \mathrm{ng} / \mathrm{ml})$ for $24 \mathrm{~h}$. After medium change, cells were treated without or with IGF-I $(100 \mathrm{ng} / \mathrm{ml})$ and/or hCG $(10 \mathrm{ng} / \mathrm{ml})$ for an additional $6 \mathrm{~h}$. Total cellular RNA was extracted. GLUT8 and L19 primer sets were added to the CDNA template, and PCR was carried out for 27 cycles. Lane S indicates standard pGEM markers, and the numbers on the left indicate sizes of the bands in base pairs. (A) A representative agarose gel and (B) GLUT8/L19 mRNA plot. 1, Control; 2, IGF-I; 3, hCG; 4, IGF-I+hCG; 5, control; 6, IGF-I; 7, hCG; 8, IGF-I+hCG $(n=4) .{ }^{*} P<0 \cdot 01$ and ${ }^{* * *} P<0 \cdot 001$ as compared with respective controls.

mediated by a family of glucose transporters (GLUTs) that are characterized by the presence of 12 membrane spanning helices and several conserved functional motifs (for review see Joost \& Thorens 2001). One of the glucose transporters, GLUT8, was found to be highly expressed in the testis. In the present study, we have confirmed that GLUT8 is expressed predominantly in testis, to a lesser extent in the heart and kidneys, and in negligible amounts in the spleen and liver. These results are in accordance with those reported by Doege et al. (2000a).

However, reports have differed regarding the timing and location of GLUT8 expression in the testis. Using Northern blotting, Doege et al. (2000a) reported that GLUT8 was not detectable in prepubertal rat testis 


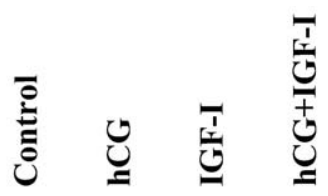

37 kD

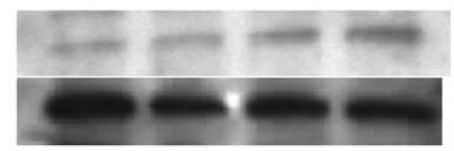

GLUT8

$43 \mathrm{kD}$

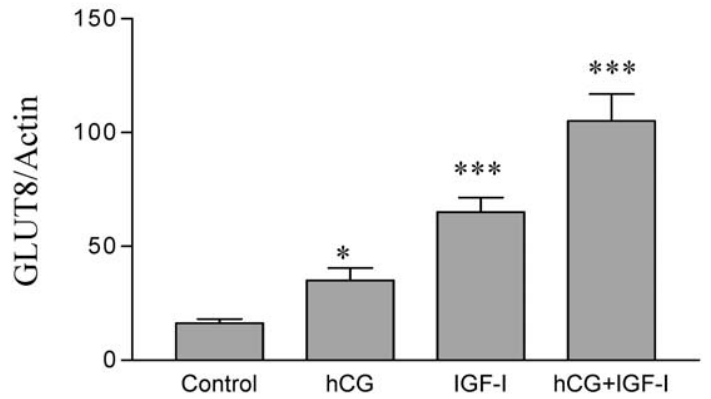

Figure 5 Effects of hCG, IGF-I or hCG+IGF-I on GLUT8 protein expression in rat Leydig cells. Leydig cells were cultured without or with IGF-I $(100 \mathrm{ng} / \mathrm{ml})$ for $24 \mathrm{~h}$. After medium change, cells were treated without or with IGF-I $(100 \mathrm{ng} / \mathrm{ml})$ and/or hCG $(10 \mathrm{ng} / \mathrm{ml})$ for an additional $6 \mathrm{~h}$. Western blot analyses for GLUT8 and $\beta$-actin were carried out. Numbers on the left indicate the sizes of the bands in kDa. Densitometric assessment of GLUT8 protein is depicted in the graph $(n=4) .{ }^{*} P<0 \cdot 05$ and ${ }^{* * *} P<0 \cdot 001$ as compared with controls.

(2 weeks old). Carayannopoulos et al. (2000) found high levels of GLUT8 mRNA in 18-day-old mouse embryonic liver and brain but did not investigate the testis. Using antibodies against a fusion protein consisting of glutathione-S-transferase and the middle loop (amino acids 203-257) of rat GLUT8, Ibberson et al. (2002) reported that GLUT8 is mainly localized in the seminiferous tubules by in situ hybridization and immunofluorescence staining. Furthermore, GLUT8 immunoreactivity was expressed in differentiating spermatocytes (preleptene, leptotene and zygotene stages of meiosis) but was undetectable in mature spermatozoa of rat testis. On the other hand, using polyclonal antiserum raised against a peptide corresponding with the C-terminus of GLUT8, Schurmann et al. (2002) found that GLUT8 is predominantly associated with the acrosomal region of mouse and human spermatozoa. The protein was not detectable before day 24 after birth. Their data suggest that GLUT8 is associated with mature spermatozoa and plays a major role in the fuel supply of sperm cells. In the present study using RT-PCR, a technique that is more sensitive than immunostaining and in situ hybridization, we found that GLUT8 was expressed in crude interstitial cells and
A

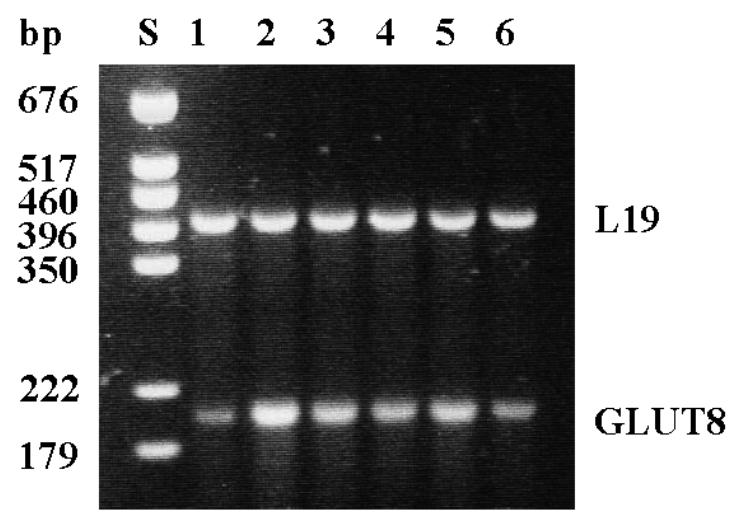

B

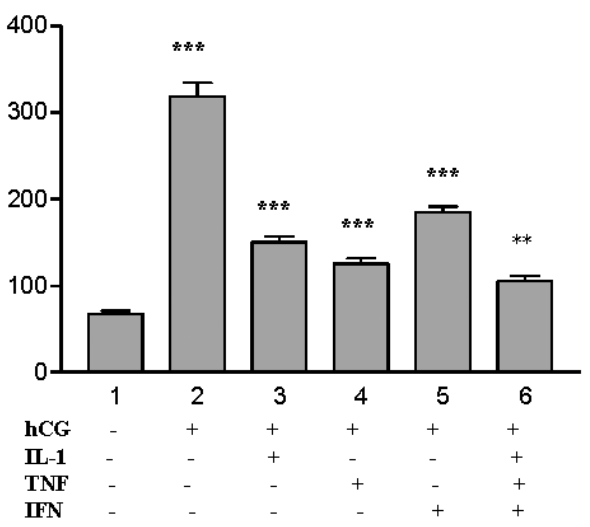

Figure 6 Effects of mIL- $1 \alpha$, mTNF- $\alpha$ and mIFN- $\gamma$ on hCG-induced GLUT8 mRNA expression. Purified adult rat Leydig cells were cultured without or with mIL-1 $\alpha(10 \mathrm{ng} / \mathrm{ml})$, mTNF- $\alpha(10 \mathrm{ng} / \mathrm{ml})$ and $\mathrm{mIFN}-\gamma(500 \mathrm{U} / \mathrm{ml})$ for $24 \mathrm{~h}$. After medium change, cells were treated with hCG $(10 \mathrm{ng} / \mathrm{ml})$ for $6 \mathrm{~h}$. GLUT8 and L19 primer sets were added to the CDNA template, and PCR was carried out for 27 cycles. Lane $\mathrm{S}$ indicates standard DNA markers, and the numbers on the left indicate the sizes of the bands in base pairs. (A) A representative agarose gel and (B) GLUT8/L19 mRNA plot $(n=4) .{ }^{* *} P<0.01$ and ${ }^{* * *} P<0.001$ as compared with basal controls without hCG or cytokine treatment.

purified Leydig cells, as well as in testicular and epididymal germ cells.

There are only limited data on the regulation of glucose uptake by Leydig cells. Both basal and LH/hCGstimulated testosterone formation increase as ambient glucose levels reach an optimum concentration (Murono et al. 1982). Furthermore, glucose uptake by Leydig cells can be blocked by cytochalasin B. Our data showed that GLUT8 expression is increased by hCG treatment, which could lead to an increase in glucose transport and testosterone synthesis by Leydig cells. In the present study, we also found that GLUT1 and GLUT3 were expressed in Leydig cells. However, neither GLUT1 nor GLUT3 mRNA were affected by treatment with hCG, IGF-I or the combination of hCG+IGF-I. This suggested that the 
effects of IGF-I and hCG on GLUT8 expression are specific and are not shared by other glucose transporters.

IGF-I has profound effects on male reproductive function. Mice in which the IGF-I and IGF-I receptor genes have been inactivated exhibit a marked reduction in the size of their reproductive organ and are infertile (Baker et al. 1993). Furthermore, serum testosterone levels are decreased to about $18 \%$ of those seen in wild-type animals (Baker et al. 1996). We have reported previously that Leydig cells express specific IGF-I receptors and that IGF-I enhances hCG-stimulated testosterone formation (Lin et al. 1986, Lin 1996). Furthermore, IGF-I up-regulates StAR and P450 scc gene expression (Lin et al. 1998b). In the present study, we have demonstrated that IGF-I and hCG have synergistic effects on GLUT8 mRNA and protein expression. Accordingly, synergistic effects of IGF-I and hCG on Leydig cell steroidogenesis may be mediated by increased GLUT8 expression. Carayannopoulos et al. (2000) reported that, in the blastocyst, up-regulation of GLUT8 by insulin is accompanied by an increase in glucose uptake. GLUT8 is mainly localized intracellularly in the basal state but, upon treatment with insulin or IGF-I, this transporter is translocated to the plasma membrane. This movement corresponds to an increase in glucose uptake, and its signal occurs via the IGF-I receptor rather than the insulin receptor.

Cytokines have profound effects on reproductive function (Calkins et al. 1990b, Imura et al. 1991, Lin et al. 1994, 1998a). IL-1 blocks hCG-induced cAMP formation and P450 scc expression and acts as a potent inhibitor of testosterone formation (Calkins et al. 1988, 1990b, Lin et al. 1991b). In insulin-sensitive tissues, cytokines downregulate GLUT4 expression (Long \& Pekala 1996) and up-regulate GLUT1 expression (Stephens et al. 1992). The IL-1-dependent increase in glucose transport by ovarian cells was found to be mediated via up-regulation of GLUT3 expression (Kol et al. 1997), while the IL-1induced increase in glucose transport by porcine synovial fibroblasts depended on the up-regulation of erythrocyte GLUT1. In human articular chondrocytes, IL-1 had no effect on GLUT3 and GLUT8 expression, whereas GLUT1 and GLUT9 were up-regulated (Shikhman et al. 2001). In the present study, we have shown that IL-1, TNF- $\alpha$ and IFN- $\gamma$ down-regulate the expression of GLUT8 in Leydig cells. Inhibition of Leydig cell steroidogenesis by cytokines is associated with decreased expression of GLUT8.

In conclusion, we have found that the GLUT8 RT-PCR product, a band of $186 \mathrm{bp}$, was detected in all of the tissues investigated, with the highest abundance in the testis, interstitial cells and purified Leydig cells. GLUT8 mRNA in Leydig cells is positively regulated by hCG and IGF-I and down-regulated by cytokines, mIL-1 $\alpha$, mTNF- $\alpha$ and mIFN- $\gamma$. These results indicate that hCG, growth factors and cytokines affect Leydig cell steroidogenesis by modulating GLUT8 expression.

\section{Funding}

This study was supported by the Department of Veterans Affairs Medical Research Fund (T L).

\section{References}

Baker J, Liu JP, Robertson EJ \& Efstratiadis A 1993 Role of insulinlike growth factors in embryonic and postnatal growth. Cell $\mathbf{7 5}$ 73-82.

Baker J, Hardy MP, Zhou J, Bondy C, Lupu F, Bellve AR \& Efstratiadis A 1996 Effects of an Igf1 gene null mutation on mouse reproduction. Molecular Endocrinology 10 903-918.

Calkins JH, Sigel MM, Nankin HR \& Lin T 1988 Interleukin-1 inhibits Leydig cell steroidogenesis in primary culture. Endocrinology 123 1605-1610.

Calkins JH, Guo H, Sigel MM \& Lin T 1990a Differential effects of recombinant interleukin-1 alpha and beta on Leydig cell function. Biochemical and Biophysical Research Communications 167 548-553.

Calkins JH, Guo H, Sigel MM \& Lin T $1990 b$ Tumor necrosis factor-alpha enhances inhibitory effects of interleukin-1 beta on Leydig cell steroidogenesis. Biochemical and Biophysical Research Communications 166 1313-1318.

Carayannopoulos MO, Chi MY, Cui Y, Pingsterhaus JM, McKnight RA, Mueckler M, Devaskar SU \& Moley KH 2000 GLUT8 is a glucose transporter responsible for insulin-stimulated glucose uptake in the blastocyst. PNAS 97 7313-7318.

Doege H, Schurmann A, Bahrenberg G, Brauers A \& Joost HG 2000a GLUT8, a novel member of the sugar transport facilitator family with glucose transport activity. Journal of Biological Chemistry 275 16275-16280.

Doege H, Bocianski A, Joost HG \& Schurmann A $2000 \mathrm{~b}$ Activity and genomic organization of human glucose transporter 9 (GLUT9), a novel member of the family of sugar-transport facilitators predominantly expressed in brain and leucocytes. Biochemical Journal $350771-776$.

Doege H, Bocianski A, Scheepers A, Axer H, Eckel J, Joost HG \& Schurmann A 2001a Characteristics of glucose transporter 10 (GLUT10), a novel heart and skeletal muscle-specific sugar transporter facilitator. Diabetes 50 (Suppl. 2) A277-A278.

Doege H, Bocianski A, Scheepers A, Axer H, Eckel J, Joost HG \& Schurmann A $2001 b$ Characterization of human glucose transporter (GLUT) 11 (encoded by SLC2A11), a novel sugar-transport facilitator specifically expressed in heart and skeletal muscle. Biochemical Journal 359 443-449.

Fukumoto H, Seino S, Imura H, Seino Y, Eddy RL, Fukushima Y, Byers MG, Shows TB \& Bell GL 1988 Sequence, tissue distribution, and chromosomal localization of mRNA encoding a human glucose transporter-like protein. PNAS 85 54345439.

Fukumoto H, Kayano T, Buse JB, Edwards Y, Pilch PF, Bell GI \& Seino S 1989 Cloning and characteristic of the major insulinresponsive glucose transporter expressed in human skeletal muscle and other insulin-responsive tissues. Journal of Biological Chemistry $2647776-7779$.

Ibberson M, Uldry M \& Thorens B 2000 GLUTX1, a novel mammalian glucose transporter expressed in the central nervous system and insulin-sensitive tissues. Journal of Biological Chemistry 275 4607-4612.

Ibberson M, Riederer BM, Uldry M, Guhl B, Roth J \& Thorens B 2002 Immunolocalization of GLUTX1 in the testis and to specific brain areas and vasopressin-containing neurons. Endocrinology 143 $276-284$

Imura H, Fukata J \& Mori 1991 Cytokines and endocrine function: an interaction between the immune and neuroendocrine systems. Clinical Endocrinology 35 107-115. 
Ishimura R, Ohsako S, Miyabara Y, Sakaue M, Kawalami T, Aoki Y, Yonemoto J \& Tohyama C 2002 Increased glycogen content and glucose transporter 3 mRNA level in the placenta of Holtzman rats after exposure to 2,3,7,8-tetrachlorodibenzo-p-dioxin. Toxicology and Applied Pharmacology 178 161-171.

Janulis L, Bahr JM, Hess RA, Janssen S, Osawa Y \& Bunick D 1998 Rat testicular germ cells and epididymal sperm contain active P450 aromatase. Journal of Andrology 19 65-71.

Joost HG \& Thorens B 2001 The extended GLUT-family of sugar/ polyol transport facilitators-nomenclature, sequence characteristics, and potential function of its novel members. Molecular Membrane Biology 18 247-256.

Joost HG, Doege H, Bocianski A \& Schurmann A 2001 Letter: Nomenclature of the GLUT family of sugar transport facilitators. GLUT6, GLUT9, GLUT10, and GLUT11. Biochemical Journal 358 791-792.

Kayano T, Fukumoto H, Eddy RL, Fan YS, Byers MG, Shows TB \& Bell GL 1988 Evidence for a family of human glucose transporterlike proteins. Sequence and gene localization of a protein expressed in fetal skeletal muscle and other tissues. Journal of Biological Chemistry 263 15245-15248.

Kayano T, Burant CF, Fukumoto H, Gould GW, Fan Y, Eddy RL, Byers MG, Shows TB \& Bell GL 1990 Human facilitative glucose transporters. Isolation, functional characterization, and gene localization of cDNAs encoding an isoform (GLUT5) in small intestine, kidney, muscle, and adipose tissue and an unusual transporter pseudogene-like sequence (GLUT6). Journal of Biological Chemistry 265 13267-13282.

Klinefelter GR, Hall PF \& Ewing LL 1987 Effect of luteinizing hormone deprivation in situ on steroidogenesis of rat Leydig cells purified by a multi-step procedure. Biology of Reproduction $\mathbf{3 6}$ 769-783.

Kol S, Ben-Shlomo I, Ruutiainen K, Ando M, Davies-Hill TM, Rohan RM, Simpson IA \& Adashi EY 1997 The midcycle increase in ovarian glucose uptake is associated with enhanced expression of glucose transporter 3. Possible role for interleukin-1, a putative intermediary in the ovulatory process. Journal of Clinical Investigation 99 2274-2283.

Lin T 1996 Insulin-like growth factor-I regulation of the Leydig cell. In The Leydig Cell, pp 477-491. Eds A Payne, M Hardy \& L Russell. Vienna, IL: Cache River Press.

Lin T, Haskell J, Vinson N \& Terracio L 1986 Characterization of insulin and insulin-like growth factor-I receptors of purified Leydig cells and their role on steroidogenesis in primary culture: a comparative study. Endocrinology 119 1641-1647.

Lin T, Wang DL, Calkins JH, Guo H, Chi R \& Housley PR 1990 Regulation of insulin-like growth factor-I messenger ribonucleic acid expression in Leydig cells. Molecular and Cellular Endocrinology 73 147-152.

Lin T, Guo H, Calkins JH and Chi R 1991 a Recombinant human monocyte-derived interleukin-1 receptor antagonist reverses inhibitory effects of interleukin-1 on Leydig cell function. Molecular and Cellular Endocrinology 78 205-209.

Lin T, Wang D, Nagpal ML, Calkins JH \& Chi R $1991 b$ Interleukin-1 inhibits cholesterol side chain cleavage cytochrome P450 expression in primary cultures of Leydig cells. Endocrinology 129 1305-1311.

Lin T, Wang D, Nagpal ML, Chang W \& Calkins JH 1992 Down regulation of Leydig cell insulin-like growth factor-I gene expression by interleukin-1. Endocrinology 130 1217-1224.
Lin T, Wang D, Nagpal ML \& Chang W 1994 Recombinant murine tumor necrosis factor-alpha inhibits cholesterol side-chain cleavage cytochrome P450 and insulin-like growth factor-I gene expression in rat Leydig cells. Molecular and Cellular Endocrinology 101 111-119.

Lin T, Hu J, Wang D \& Stocco DM 1998a Interferon- $\gamma$ inhibits the steroidogenic acute regulatory protein messenger ribonucleic acid expression and protein levels in primary cultures of rat Leydig cells. Endocrinology $1392217-2222$.

Lin T, Wang D, Hu J \& Stocco DM 1998 b Up-regulation of human chorionic gonadotropin-induced steroidogenic acute regulatory protein by insulin-like growth factor-1 in rat Leydig cells. Endocrine $873-78$.

Long SD \& Pekala P 1996 Regulation of GLUT4 mRNA stability by tumor necrosis factor- $\alpha$ : alternations in both protein binding to the $3^{\prime}$ untranslated region and initiation of translation. Biochemical and Biophysical Research Communications 220 949-953.

McVie-Wylie AJ, Lamson DR \& Chen YT 2001 Molecular cloning of a novel member of the GLUT family of transporters, SLC2A10 (GLUT10), localized on chromosome 20q13.1: a candidate gene for NIDDM susceptibility. Genomics 72 113-117.

Manna PR, Dyson MT, Eubank W, Clark BJ, Lalli E, Corsi PS, Zelenik AJ \& Stocco DM 2002 Regulation of steroidogenesis and the steroidogenic acute regulatory protein by a member of the cAMP response-element binding protein family. Molecular Endocrinology 16 184-199.

Mueckler M, Caruso C, Baldwin SA, Panico M, Blench I, Morris HR, Allard WJ, Lienhard GE \& Lodish HF 1985 Sequence and structure of human glucose transporter. Science 229 941-945.

Murono EP, Lin T, Osterman J \& Nankin HR 1982 Relationship between inhibition of interstitial cell testosterone synthesis by cytochalasin B and glucose. Biochemical and Biophysical Research Communications 104 299-306.

Phay JE, Hussain HB \& Moley JF 2000 cloning and expression analysis of a novel member of the facilitative glucose transporter family, SLC2A9 (GLUT9). Genomics 66 217-220.

Saez JM 1994 Leydig cells: endocrine, paracrine and autocrine regulation. Endocrine Review 15 574-626.

Schurmann A, Axer H, Scheepers A, Doege H \& Joost H-G 2002 The glucose transport facilitator GLUT8 is predominantly associated with the acrosomal region of mature spermatozoa. Cell and Tissue Research 307 237-242.

Shikhman AR, Brinson DC, Valbracht J \& Lotz MK 2001 Cytokine regulation of facilitated glucose transport in human articular chondrocytes. Journal of Immunology 176 7001-7008.

Sosa MA, Barbieri MA \& Bertini F 1991 Binding of beta-galactosidase from rat epididymal fluid to the sperm surface by high-affinity sites different from phosphomannosyl receptors. Journal of Reproduction and Fertility 93 279-285.

Stephens JM, Carter BZ, Pekala PH \& Malter JS 1992 Tumor necrosis factor $\alpha$-induced glucose transporter (GLUT1) mRNA stabilization in 3T3-L1 preadipocytes: regulation by the adenosineuridine binding factor. Journal of Biological Chemistry 267 8336-8341.

Received in final form 10 July 2003

Accepted 16 July 2003

Made available online as an

Accepted Preprint 21 July 2003 